
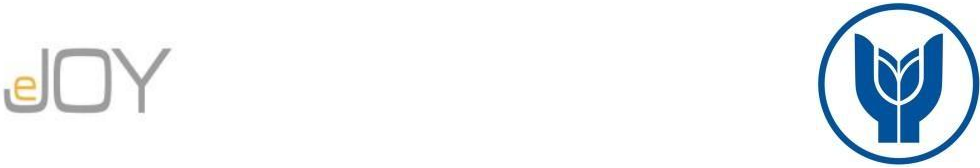

Ocak, S., Yurdakul, D. / Journal of Yasar University, 2021, 16/62, 835-866

\title{
Tüketicilerin Koçluk Hizmetlerine Yönelik Tercih ve Tutumları:Türkiye'de Yaşam Koçluğu Üzerine Bir Çalışma
}

\section{Consumer's Preferences and Attitudes Towards Coaching Services: A Study on Life Coaching in Turkey}

\author{
Sinem OCAK, Altınbaş Üniversitesi, Türkiye, sinem.ocak@altinbas.edu.tr \\ Orcid No: 0000-0001-6058-9265 \\ Dicle YURDAKUL, Altınbaş Üniversitesi, Türkiye, dicle.yurdakul@altinbas.edu.tr \\ Orcid No: 0000-0001-9026-8606
}

\begin{abstract}
Öz: Günümüzde bireylerin kişisel gelişime olan ilgisinin artması ile koçluk hizmetlerinin de önem kazandiğ gözlenmektedir. Koçluk hizmeti birçok farklı alt uzmanlık alanı ile çeşitlendirilmekte olup, yaşam koçluğu ise koçluk hizmetleri arasında en çok tercih edilen koçluk dalıdır. Bu çalışma, tüketicilerin yaşam koçluğu hizmeti tercihlerini incelemekte ve koçluk hizmeti satın alımında dikkate alınan faktörleri araştırmaktadır. Çalışma kapsamında uygulanan anket ile Türkiye'de tüketicilerin yaşam koçluğu hizmeti satın alma kararında rol oynayan ana unsurların ortaya çıkarılması amaçlanmıştır. 214 katılımcı ile gerçekleştirilen çalışmanın bulgularına göre, tüketiciler yaşam koçluğu hizmeti alırken kalite, ücret, süre, koçun eğitim düzeyi, motivasyonu ve tecrübesini göz önünde tutmaktadır. Cinsiyet ve gelir düzeyi katılımcıların yaşam koçluğuyla ilgili tercihleri üzerinde anlamlı bir farklılı̆̆a neden olmazken, daha önce koçluk hizmeti alanlarla almayanların görüşlerinin ise anlamlı derecede farklılaştığ tespit edilmiştir.
\end{abstract}

Anahtar Sözcükler: Koçluk, Yaşam Koçluğu, Koçluk Hizmeti, Tüketici Tercihi

JEL Sinıflandirmasl: D11, D91, M00, M30, M37

\begin{abstract}
Nowadays, it is observed that coaching services gain importance with increasing interest of individuals to personal development. Coaching is diversified with many different subspecialties and life coaching is the most preferred coaching branch among the coaching services. This study examines consumers' life coaching service preferences and investigates the factors that are taken into account in coaching service purchase decision. Through the survey adapted, it was aimed to identify the main factors influencing the purchase decision of life coaching services by consumers in Turkey. According to the findings of the study conducted with 214 participants, consumers consider quality, wage, duration, education level, motivation and experience of the coach as important factors when receiving life coaching services. While gender and income level did not cause a significant difference on the preferences of the participants about life coaching, it was found that the opinions of the participants who did not receive coaching services previously differed significantly from the ones who received such services.
\end{abstract}

Keywords: Coaching, Life Coaching, Coaching Services, Consumer Preference

JEL Classification: D11, D91, M00, M30, M37

\section{Giriş}

Günümüzde kişisel gelişime olan ilginin artması ile koçluk hizmetlerinin de önem kazandığı gözlenmektedir. Bireyler çeşitli sebeplerle koçluk hizmeti satın almaya ihtiyaç duymakta, bu durum da pek çok farklı alt koçluk dalının ortaya çıkmasına neden olmaktadır. Performans koçluğu, yönetici koçluğu, iş koçluğu gibi pek çok alt alana yayılan koçluk hizmetleri arasında gerek dünyada gerekse ülkemizde en çok tercih edilen koçluk dallarından biri ise 
yaşam koçluğudur. Bu çalışma, giderek büyüyen bir pazar olan koçluk hizmetleri pazarında, yaşam koçluğu dalı özelinde tüketici tercihlerini etkileyen faktörleri incelemektedir.

Dilimize, İngilizce “coaching” kelimesinden gelmiş olan koçluk, Türkçe'de koçluğu karşılayan başka bir terim olmaması sebebiyle dilimize Türkçe okunuşu olan "koç" şeklinde yerleşmiştir. Türk Dil Kurumu sözlüğünde (2019) "koçluk” kavramı "Kişilerin liderlik veya yöneticilik özelliklerini, becerilerini geliştirmeye yönelik, belli bir amacı hedefleyerek daha etkili sonuçlara ulaşmasını sağlamak üzere verilen hizmet” tanımı ile yer almaktadır. Uluslararası Koçluk Federasyonu (ICF) tarafından ise koçluk, "günümüzün belirsiz ve karmaşık ortamlarında özellikle önemli olan, kişisel ve mesleki potansiyeli en üst düzeye çıkarmak için ilham veren, düşünmeye teşvik eden ve yaratıcı bir süreçte müşteri ile ortaklık ilişkisi” olarak tanımlanmaktadır.” (ICF, 2019).

Türkiye'de koçluk kavramının ve hizmetlerinin popüler hale gelmesi ile gerek arz gerekse talep tarafında bir artış olduğu gözlenmektedir. Türkiye'de faaliyet gösteren koçların tamamının profesyonel bir örgüt ile bağlantısı olmaması nedeniyle profesyonel koçluk hizmeti sunan kişilerin sayısı tam olarak bilinememektedir. Uluslararası Koçluk Federasyonu (ICF) Türkiye yapılanmasının, Uluslararası Profesyonel Koçluk Derneği tüzel kişiliğinde 2018 yılında 450 üyesi mevcut olup, bu üyelerinden 232'sinin kayıtlı koçluk yapanlardan oluştuğu tespit edilebilmektedir. ICF Türkiye üyeleri içinde Bireysel Koçluk alanında Türkiye genelinde faaliyet gösteren 162 üye mevcuttur (ICF Türkiye 2016). Söz konusu rakamlardan da anlaşılacağı üzere koçluk hizmetlerine ilgi artmakta, bu hizmet alanı önemli bir pazar potansiyeli vaad etmektedir. Buna karşın, yapılan literatür araştırmasında konu ile ilgili yapılan çalışmaların oldukça kısıtlı olduğu görülmüş ve bu konu özelinde geliştirilen herhangi bir ölçüm aracına rastlanamamıştır. $\mathrm{Bu}$ nedenle bu çalışma, tüketicilerin yaşam koçluğu hizmeti tercihlerini incelemek ve tüketicilerin yaşam koçluğu hizmeti satın alımında hangi faktörlerin etkili olduğunu ortaya çıkarmak sureti ile, dünyada ve Türkiye'de giderek büyüyen bir pazar olan koçluk hizmetleri alanına ilişkin literatüre katkıda bulunmayı amaçlamaktadır.

Çalışma dört bölümden oluşmaktadır. İlk bölümde; kavramsal çerçeveye yer verilerek, koçluk tanımı, becerileri, çeşitleri ile mesleğe ilişkin kavramlar detaylandırılmakta ve bu alandaki mevcut çalışmalara değinilmektedir. İkinci bölümde araştırmanın yöntemi açıklanmakta; üçüncü bölümde ise yaşam koçluğu hizmeti satın alma kararını etkileyen faktörlere ilişkin olarak, araştırmacılar tarafından gerçekleştirilen anket geliştirme süreci, ölçek güvenilirliği ve bu ölçek vasıtası ile elde edilen verilerin analizine yer verilmektedir. Son bölümde araştırma sonuçları yorumlanarak, öneriler sunulmaktadır. 


\section{Literatür Taraması}

\subsection{Koçluk Kavramı ve Tanımı}

Koçluk mesleğinin önemi her ne kadar son yıllarda artmış olsa da, kavram olarak tarihi çok eskilere dayanmaktadır. Eğitimden bilime, kişisel gelişimimen spora değin birçok alanda karşımıza çıkan koçluk, aynı zamanda iş hayatında da önemli bir yere sahiptir. Özellikle iş yaşamında çalışan memnuniyeti ve tatminine ilişkin sağladığı faydalardan dolayı adından s1kça söz ettirmektedir (Çetin, 2015; Gezer, 2016). Koçluk, son zamanlarda özellikle üzerinde durulan bir kavram olmakla birlikte, bu kavramı açıklamak üzere pek çok tanım yapıılmış ve alt uzmanlık alanları ortaya konulmuştur. Buradan yola çıkarak genel olarak koçluğu, bireylerin ve işletmelerin performanslarını ve gelişimlerini daha üst seviyeye çıkararak, verimliliklerini arttırmayı hedefleyen ve karşılıklı iletişimi esas alan bir süreç olarak tanımlamak mümkündür. Her geçen yıl yaygınlaşması hızlanan koçluk hizmetleri, bu yaygınlaşmaya paralel olarak, tüm dünyada mevcut meslekler arasındaki yerini alma, tercih edilir olma yolunda genç bir meslektir. (ICF Turkey, 2020)

Literatürde koçlukla ilgili birçok farklı tanım yer almaktadır. Dă̆ (2010), koçluk kavramını "insanların yaşamlarında, kariyerlerinde, iş hayatlarında veya yönetim becerilerinde mükemmel sonuçlar elde etmesine yardımcı olan, süregelen profesyonel bir ilişki” olarak tanımlamaktadır. Kişisel gelişim sürecine hız kazandıran koçluk, kişinin mevcut durumunu inceleyerek, gelecekte varmak istediği noktaya ulaşmasına destek olmaya odaklanan bir süreçtir. Diğer yandan, farklı tanımlarda koçluğun kişileri, kendilerini geliştirmeleri, sorunlarına çözüm bulabilmeleri ve hedefledikleri noktaya varabilmeleri için gerekli bilgi ve becerilerle donatmayı da içerdiğine yer verilmektedir (Peterson ve Hicks, 1996).

Koçlukla ilgili yapılan tanımlamaların hemen hepsi birbirinden farklı olsa da tüm tanımlarda ortak bir noktanın olduğunu söylemek mümkündür. Koçluk; amaca ulaşmak için farkındalığı arttırarak, bireylere yol gösterme, yardımcı olma ve performanslarını geliştirerek, çeşitli davranışsal beceriler kazandırma sürecidir. Bu tanım çerçevesinde koçluk kavramının temel noktası birey ve/veya gruplardır. Koçluğun amacı da bireylere yahut gruplara kendi başına hareket edebilme kabiliyetini öğretme ve geliştirmedir (Kalkavan, 2014).

Tüm koçluk tanımları gözden geçirilerek literatüre katkı sunmak amacıyla koçluk kavramı, yazarlar tarafından şu şekilde tanımlanmaktadır: Koçluk, bireylere, farkında oldukları ya da yapılan görüşmelerle farkındalık kazandırılarak belirlenen bir amaç doğrultusunda, bulunulan noktadan hedeflenen noktaya varmak için, karş1lıklı güven 
çerçevesinde, problem çözme becerisi, performans ve pozitif ivme kazanma yolunda rehberlik etme sürecidir.

Günümüzde danışmanlık ve mentorluk kavramlarının sıklıkla koçluk kavramı ile eş anlamlı olarak kullanıldı̆̆ı görülmektedir. Halbuki bu kavramlar önemli farklılıklar taşımaktadır. Koçlukta bulunulan noktadan da başarıyı elde edebilmek için danışan geliştirilmeye çalışılırken, danışmanlıkta daha ziyade danışanın problemlerine ilişkin çözüm önerileri geliştirilmeye çalış1lır. Bir başka deyişle koçlukta, öğrenen bireyin öğrenimi kolaylaştırılmaya çalışılırken danışmanlıkta ise öğrenen kişinin karşılaştı̆ğ problemler hakkında çözüm önerileri geliştirilir ve kendisinden bu tavsiyelere ve önerilere uyması beklenir. Koçlukta, danışan kişi soruları ile ilgili cevapları kendisi bulur; koç bu aşamada yalnızca danışanı bu cevapları bulma konusunda destekler. Bunun yanında danışmanın faaliyet gösterdiği alanla ilgili uzman olması gerekirken, koçun faaliyet gösterdiği alanla ilgili uzman olmasına gerek yoktur. Koç çözüme odaklıyken, danışman probleme odaklıdır (Kalçık, 2018; Çatalbaş, 2016).

Koçluk ve mentorluk kavramları, sürece dayanan ilişki, yardım, yol gösterme, öğretme ve gelişim süreçleri gibi ortak bir takım süreçleri içermektedir. Öte yandan, mentorluğu koçluktan ayıran en önemli nokta ise mentorun kaynak işlevi görmesidir. Yani mentor kendi bilgi birikimi ve tecrübesini öğrencisine aktarmaktadır. Ancak koçun görevi bireyin performansını arttırabilmek için farkındalık yaratmaktır. Koçlukta kişinin kendi potansiyelinden yola çıkılmaktadır. Koçluk, bireyin kendi belirlediği hedefe ulaşabilmek için karşılaştığı sorunlara çözüm üretebilmesini, mücadele edebilmesini ve doğru kararlar alarak kendini geliştirmesini sağlar (Çetin, 2015; Büngül, 2015).

ICF Türkiye (2021)'ye göre, profesyonel koçlar sanılanın aksine tavsiye vermezler. Koçlar, müşterinin varmak istediklerini keşfetme, netliğe kavuşturma, müşterisi ile uyum sağlama, müşterisinin kendisini keşfetme yolculuğunda teşvik etme, müşteriye alan açarak kendi çözümlerini bulmasına destek olma, müşteriyi kendi yaşamından sorumlu ve hesap verebilir kılma gibi sorumlulukları taşımaktadır.

\subsection{Koçluk Hizmetinin Gerektirdiği Yetkinlikler}

Koçluk, etkili becerilere sahip olabilmeyi ve sürekli kendini geliştirebilmeyi gerekli kılmaktadır. Etkili ve doğru bir koçluk; gerekli becerileri ve yaklaşımları kullanarak bu süreci kontrol edebilmeyi gerektirir. Koçun etkili bir koçluk süreci yaratabilmesinde sahip olması gereken temel beceriler şunlardır (Çavuşoğlu, 2015): 
Dinleme Becerisi: Koçlukta tüm süreç dinlemeye dayanmaktadır bu nedenle koçun en önemli becerisinin dinleme olduğunu söylemek mümkündür. Etkin dinleme; kendini iç sesini susturmak ve karşıdaki kişiye odaklanarak algıları açık tutmak ile mümkün olmaktadır. İyi bir dinleyici olan koç, karşısındaki kişinin düşüncelerini yetersiz görse dahi yapıcı bir tutum takınır ve yeni fikirlerin oluşması için çaba gösterir. Bir koçun danışanın düşüncelerini istenilen yönde değiştirebilmesi için danışanı dinleyerek onu anlaması esastır (Çavuşoğlu, 2015; Büngül, 2015; Aydar,1999).

Sorgulama Becerisi: Koçluk sürecinde doğru ve yerinde sorulan sorular büyük önem arz etmektedir. Doğru ve zamanında sorulan sorular sayesinde gündem belirlenir, danışan hakkında bilgi edinilir ve hedef belirlenir. Koç, kişiye problem teşkil eden durumları, performansını, yetersizliklerini ve bunların nedenlerine ilişkin soruları sorarak, bireyin fikirlerini açıklamasını ve etkili bir iletişimi sağlar (Elgün,2007; Büngül, 2015). Güçlü soruların sorulması ve koçlar tarafından sorgulama becerisinin etkili şekilde kullanılması danışan hakkında daha fazla bilgi edinmesine yardımcı olacak, gizli kalan yetilerin daha iyi ortaya çıkmasını sağlayacak ve görüşme konusunun anlaşılıp anlaşılmadığını öğrenmeye yarayacaktır (Büngül, 2015).

Gözlem Becerisi: Gözlem becerisi bireyin neler iyi yapıp yapmadığı, eksiklikleri, yeteneklerinin hangi düzeyde olduğu, geliştirmesi gerekli olan alanların neler olduğu konularında veri toplamak ve bunları değerlendirilerek hedeflerin belirlenebilmesi açısından koçun sahip olması gereken bir özelliktir. Koç danışanı gözlemlerken tarafsız davranmaya dikkat etmelidir. Bir başka deyişle koç, danışanı gözlemlerken sabit fikirli olmaktan uzak durmalıdır (Mcmanus, 2007).

Analiz ve Sentez Becerisi: Koç, kurduğu etkili iletişim vasıtasıyla danışanının problemlerini ya da problem olabilecek durumları analiz etmelidir (Burke ve Collins, 2001). Koçlar, danışanın sorunlarını anlayarak, bu sorunları danışanın da anlayıp değiştirebilmesi için katkıda bulunurken analiz ve sentez becerisinden faydalanmaktadır.

Öğrenmeyi Öğretme Becerisi: Koç, danışanına ne öğrenmesi gerektiğini söylememelidir. Bunun yerine ne öğrendiğini kendi kendine sorgulamasını sağlayarak aldığı yolu görmesini sağlamalıdır (Kalkan, 2009). Russel'e göre (2007), koçluğun asıl hedefi öğretmek olmamalıdır. Bunun yerine koç, çeşitli sorular sorarak neyi öğrenmesi gerektiğine dair danışanı yönlendirmelidir. (Gökçek, 2006). 
Dönüt Verme: Dönüt verme öğrenmenin en önemli parçalarından biridir (Yurdakul, 2010). Dönüt verme, sorularla çıkılan yolda önemli bir itici güçtür. Doğru dönüt verme, koçluğun koç tarafından sorun çözücü ve içten bir şekilde takviye edilmesidir.

Koçluk hizmeti veren kişinin söz konusu becerileri edinmiş ve geliştirmiş olması koçluk hizmetinin algılanan kalitesine katkıda bulunacak unsurlar arasındadır. Tüketiciler, bu faktörleri bilinçli olarak değerlendirmeseler dahi, bu becerilere sahip kişiler tarafından verilen koçluk hizmetini almaları durumunda aldıkları hizmetin algılanan kalitesi artacaktır (Çavuşoğlu, 2015).

\subsection{Yaşam Koçluğu}

Koçluk sadece bireyi esas almaktan ziyade bireyi, içerisinde bulunduğu sistemle birlikte ele alır ve asıl amacı sistemle birey arasındaki dengenin sağlanması ve ilişkinin düzenlenmesidir. $\mathrm{Bu}$ ihtiyaç doğrultusunda da farklı koçluk türleri ortaya çıkmıştır. Alınan koçluk hizmetinin türü her ne olursa olsun, asıl amaç her zaman değişim sürecinde işlemin uyumunu sağlayabilmek ve bireylerin duygusal dengesini korumak için yeni bakış açıları kazandırmaktır (Poussard, 2004).

Günümüzdeki anlamı ile yaşam koçluğunun temelleri Amerikan spor dünyasına dayanmaktadır. Yaşam koçları da spor koçları gibi danışmanlığını yürüttükleri kişileri cesaretlendirmeyi, motivasyon ve morallerini arttırmayı ve dolayısı ile başarıya ulaşmalarını sağlamayı hedeflemektedirler. Benzer şekilde, iş dünyasında da yüksek motivasyona sahip, huzurlu ve mutlu çalışanların daha üretken olduklarını fark eden şirket yöneticileri koçlarla çalışmaya yönelmişlerdir (Mumford, 2007). Yöneticilerin, çalışanların veya işletmelerin daha başarılı olabilmek için eğitim almaya ek olarak kendilerini kişisel olarak geliştirmek için de gayret göstermeleri gerektiği ifade edilebilir. Koçluk eğitiminde resmi bir eğitim süreci olmamasından kaynaklı olarak bu kişisel gelişim yöntemi, öncelerde yapılan danışmanlık verme, şimdilerde ise yaşam koçluğu anlamına gelmektedir. Yaşam koçluğu, kişinin farklı hedeflerine ve isteklerine odaklanan bir kişisel geliştirme içeriğinin hazırlandığı ve uygulandığı bir süreç olarak tanımlanabilir (Akçil, 2012). Yaşam koçluğu, gizlilik esas alınarak danışanın tüm hayatına yönelik bir koçluğu temsil eder. Danışanın hayatındaki bir sorunun veya sorunun hayatına olan belirli bir etkisinin koçun yardımı ile ortadan kaldırılması hedeflenir (Reiss, 2004). 
Yaşam koçluğu, kişilere iş hayatları haricinde oluşturdukları amaçlara varmalarında kolaylık sağlamayı amaçlar. Hayatlarının devam eden dönemlerinde daha fazla başarı elde etmeyi arzulayan kişiler, noksanlığını duydukları alanlarda profesyonel olarak yardım alırlar. Öfke kontrolü, zaman yönetimi, stresle mücadele edebilme ve benzeri konu başlıkları bu eğitimin bir parçası olabilir (Underhill ve ark., 2007). Yaşam koçluğunda danışanların doğru yönde ilerlemesini kolaylaştırmak için sohbet bir araç olarak kullanılır. Bu sohbet 'Neden bu biçimde ilerlemeyi tercih ettin?', 'Bu fiili gerçekleştirmekten seni alıkoyan şey nedir?', 'Gerçekteki seçeneklerin neler?', 'Motivasyonunu nasıl devam ettirebilirsin?' gibi sorular ile yönlendirilerek, bu sayede bireylerin doğru yönde ilerlemelerinin sağlanması amaçlanır (Mumford, 2007). Böylelikle kişi bu sorular ile ilgili en doğru cevapları bulacak ve bunu mantıklı bir süreçten geçerek yapacağı için dolaylı olarak da kişinin en doğru olanı kendisinin keşfetmesi sağlanacaktır.

Yaşam koçluğu, bir diğer adıyla kişisel koçluk, son yıllarda ülkemizde de en çok ilgi gören koçluk dallarından birisidir (Kalkavan, 2014). Yaşam koçluğu alan bireylerin bireysel ve toplumsal olaylarla daha başarılı bir şekilde başa çıkabildikleri düşünülmektedir. Yaşam koçu ile çalışan bireylerin bu hizmete inançlı bir şekilde yaklaşmasının, kişinin daha çok verim almasını sağlamasına ek olarak, hedeflerini daha net bir şekilde belirlemelerime de yardımcı olduğu görülmektedir. Kaygılarının ve korkularının yerine güven duygusunun geçtiği yaşam koçluğu alan bireyler, kendi eksikliklerini daha net bir şekilde görebilmektedir ve yaşamları ile ilgili kararları daha sağlam adımlarla atabilmektedir. Ayrıca yaşam koçluğu alan bireylerin kendi bilgi ve becerilerini daha bilinçli ve doğru bir şekilde yönlendirdiği de bilinmektedir (Çakar, 2011). Yaşam koçluğu aynı zamanda bireylerin kariyer ve iş performanslarına da katkıda bulunmaktadır. Bu nedenle yaşam koçluğu, kişisel ve sosyal gelişime katkı sağlayan bir kişisel gelişim yöntemi olarak da bilinmektedir (Eryılmaz, 2014). Koçluğun içeriğini ve amacını danışanın kendisinin belirlemesinden kaynaklı olarak bireylerin farkındalıkları gelişmekte ve hedeflerine ulaşma sürecinde karşılaştıkları engeller ile daha yeterli bir şekilde başa çıkabilmektedirler (Yurdakul, 2010).

\subsection{Koçluk Hizmeti ve Tüketicilerin Seçim Kriterleri}

Koçluk hizmetlerine dair yerel literatürde yapılmış olan önceki çalışmalarda, bu hizmetlerin bireysel ve kurumsal düzeyde yarattığı fayda ve bu faydaya ulaşma yolunda tüketicilerin değerlendirmeye aldıkları seçim kriterlerine ilişkin sınırlı sayıda çalışma bulunmaktadır. Akın ve Ulukök (2017) koçluğun iş göre üzerinde etkisini araştırdıkları çalışmalarında, koçluğun kurumlarda çalışanları geliştiren olumlu bir mekanizma olduğunu ortaya koymuşlardır. 
Araştırma bulgularına göre koçun görevleri; yeterlikleri geliştirmek, çalışanları etkileyebilmek, kurum içi iletişimi sağlamak, ödüllendirme sistemini düzenlemede yardımcı olmak, çalışan motivasyonunu arttırmak, performans değerleme, stres azaltma ve liderlik süreçlerinde yardımcı olmaktır. Benzer şekilde, Barutçu ve Özbay (2013) araştırmalarında değişen ve gelişen teknolojiyle birlikte örgütlerin kendilerini geliştirmek ve daha ileri gitmek için koçluğa ihtiyaç duyduklarını belirtmişlerdir. Koçluk, kişilerin öğrenmelerini etkinleştiren, çeşitli beceriler kazanmalarına vesile olan ve performanslarını arttıran bir süreçtir. $\mathrm{Bu}$ araştırmanın sonuçlarına göre koçluk, yöneticilerin ve çalışanların performansını, iletişim becerilerini ve problem çözme becerilerini arttırmaktadır.

Eğitim koçluğu alanında yapılan çalışmaların da bireysel ve kurumsal düzlemde benzer bulgulara ulaştıkları görülmektedir. Kalçık (2018) araştırmasında öğrenci koçluğu eğitimi almış uzmanların görüşlerini ortaya çıkarmayı amaçlamıştır. 7 değişik ilde çalışan ve uluslararası öğrenci koçluk belgesi olan 12 öğrenci koçu ile yapılan mülakatların neticesinde öğrenci koçluğunun kişisel gelişim ve başarıyı arttırmadaki etkisi ortaya koyulmuştur. Yine eğitim koçluğu alanında yapılan bir başka çalışmada Knight (2006), eğitim koçluğunun öğretmenlerin öğretme şeklini ve öğrencilerin öğrenme şeklini geliştirmek için çok büyük bir potansiyele sahip olduğunu, ancak bu potansiyelin gerçekleşmesinin koçluk programının tasarımıyla yakından ilintili olduğunu ileri sürmektedir.

Koçluk hizmeti alımı sonucunda yaratılan etkiye ilişkin olarak yapılan diğer çalışmalarda, koçluğun başarı umudu ve iyi oluş durumunu pozitif yönde etkilediği, bilişsel güç, zihin sağlığı ve bununla birlikte umutlu olma durumunu arttırdığ (Green, Oades ve Grant, 2006), bireysel mutluluk ve olumlu mutluluğu arttırdığı (Green ve Grant, 2005), hedefe ilerlemede teşvik edici unsuru ile stres ve kaygıda azalma sağladığı (Grant, 2003a) ve hedef odaklılık, mutluluk ve algılanan yaşam kalitesinde artışa neden olduğu (Grant, 2003b; Green, Oades, ve Grant, 2005) bulgularına ulaşılmıştır. Ayrıca koçluk, profesyonel ortamda bireylerin bağlılık amacına, kararlılık amacına ve çevresel hakimiyetlerine (Spence ve Grant, 2010), liderlerin yetkinliklerinin, ekip dinamiğinin ve çalışma atmosferinin geliştirilmesine, ayrıca özellikle pandemi dönemi gibi beklenmedik koşulları beraberinde getiren süreçlerde, çalışanların motivasyonlarının ve iş-yaşam dengelerinin korunmasına kaktıda bulunmaktadır (Güler, 2020).

Koçluk hizmeti alma kararını etkileyen faktörler üzerine ise yerli ve yabancı literatürde kısıtlı sayıda araştırma yapıldığı görülmektedir. Wasylyshyn (2003) araştırmasında, yönetici koçluğu uygulamasının hızla artmayı sürdürdügünü ancak sonuçlarıyla ilgili çok az araştırma yapıldığını belirtmiştir. Araştırmada koçluk hizmeti alımını etkileyen faktörler arasında 
yöneticilerin bir koçla çalışılmasına tepkileri, hem iç hem de dış koçların artıları ve eksileri, yönetici koçluğu çalışmalarının odağı, başarılı koçluk örnekleri gibi konular üzerinde durulmuştur. Ayrıca, araştırma bulgularına göre koçluk uygulamalarının yöneticiler tarafından tercih edildiği ve koçlu yöneticilerin öğrenme ve davranış değişikliklerinde bulundukları tespit edilmiştir. Kurumlarda koçluk hizmeti tercihinde en önemli unsurlardan birinin ise yatırım maliyeti olduğu görülmektedir. İç koç görevlendirme ve dış koçtan hizmet alma tercihi ise, yatırım maliyetini etkileyen en önemli unsurdur. Maliyeti etkin kılmak için, dış koç hizmetine kıyasla iç koç kullanmak tercih edilmektedir. (Yıldırım, 2011; CastilloRamsey,2011; Woods ve Guillaume, 2015; Weinstein, 2017). Öte yandan,yine iş dünyas1 açısından önem arz eden bir koçluk alanı olan performans koçluğu hizmetinin tercihinin ise bireylerin performans ve verimlilik motivasyonları ile ilintili olduğu görülmektedir (Zeus, P. ve Skiffington, S., 2004).

Genel anlamda koçluk ve özellikle yaşam koçluğu üzerine, koçluk hizmetlerinin tercihinde rol oynayan faktörler ve tüketici tutumlarına ilişkin yapılan çalışmaların sayısı oldukça kısıtlıdır. Oysa ki tüketicilerin, yaşam koçluğu hizmetine ilişkin tutumlarının ve koçluk hizmeti satın alma kararlarını etkileyen faktörlerin ortaya çıkartılması, giderek gelişmekte olan bu hizmet alanında faaliyet gösteren kişi ve kurumlar için büyük önem arz etmektedir. $\mathrm{Bu}$ çalışma bu amaçla yola çıkarak gerçekleştirilen araştırma vasıtasıyla, Türkiye'deki tüketicilerin yaşam koçluğu hizmeti satın alma kararlarını etkileyen faktörleri ve hangi faktörlerin satın alma kararında daha ağırlıklı bir rol oynadığını tespit etmeyi amaçlamaktadır.

\section{Yöntem}

Tüketicilerin yaşam koçluğuna ilişkin görüş ve tutumlarını ortaya çıkarmayı amaçlayan bu çalışmada nicel araştırma yöntemlerinden yararlanılmıştır. Araştırmanın evrenini Türkiye'de 25 yaş üzeri ve kendi gelirini elde eden yetişkin bireyler oluşturmaktadır. Örneklem belirlenirken kolay ulaşılabilir tekniği kullanılmıştır. Kolay ulaşılabilir durum örneklemesi, araştırmacının hali hazırda mevcut bulunan, erişilmesi hızlı ve kolay olan katılımcılardan örneklem oluşturması esasına dayanır. Belirlenen kriterlere uygun olan durum örneklemesi ile 214 katılımcı örneklemde yer almıştır. Örnekleme ait demografik veriler Tablo 1'de sunulmuştur. 
Tablo 1. Örnekleme Ait Demografik Veriler

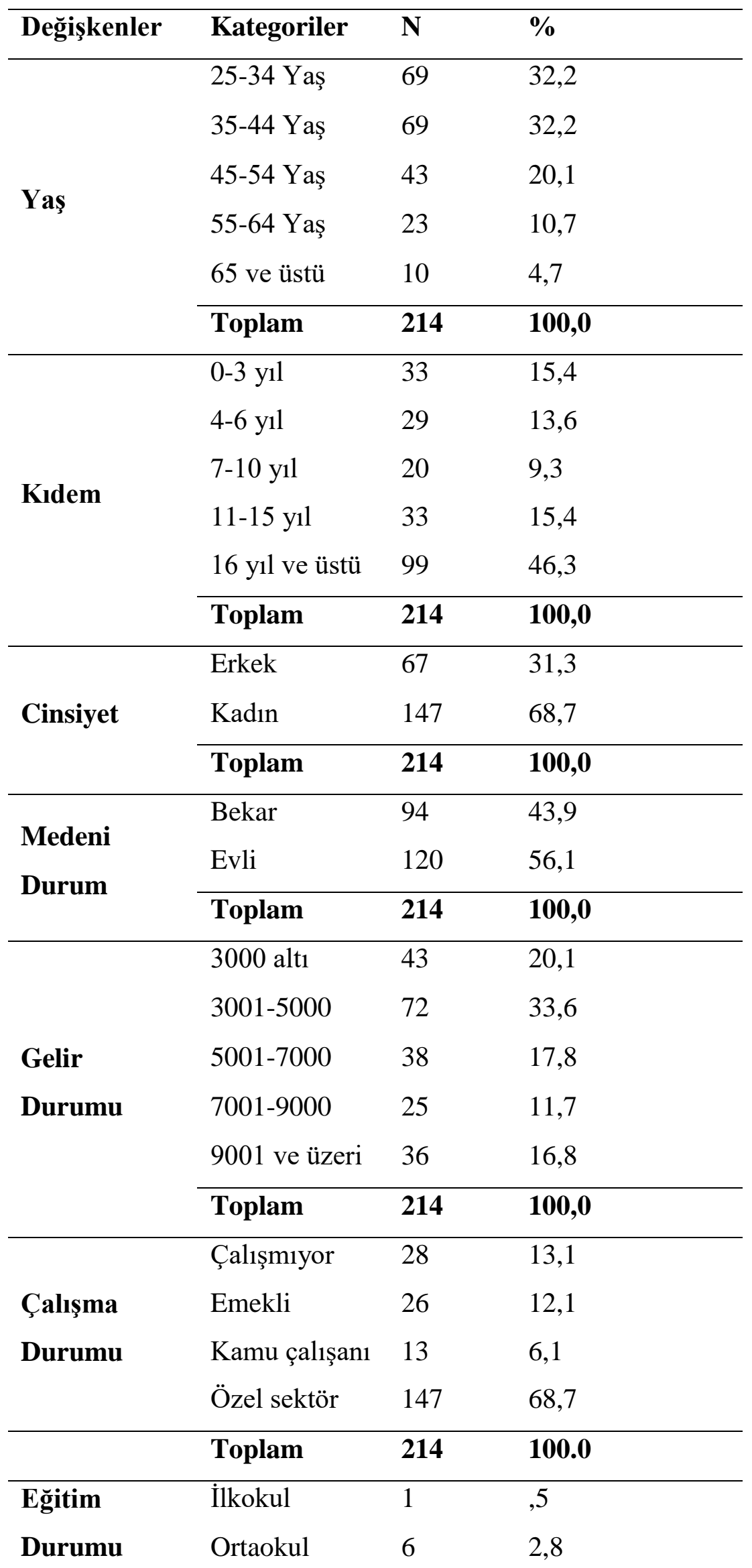




\begin{tabular}{lll} 
Lise & 30 & 14,0 \\
Lisans & 117 & 54,7 \\
Yüksek lisans & 42 & 19,6 \\
Doktora & 18 & 8,4 \\
\cline { 2 - 3 } Toplam & $\mathbf{2 1 4}$ & $\mathbf{1 0 0 , 0}$
\end{tabular}

Tablo 1'de görüleceği üzere katılımcıların yaklaşık \%65'i 25-44 yaş aralığındadır. Katılımcılar Türkiye'nin farklı illerinde, ağırlıklı olarak büyük şehirlerde ikamet etmektedir. Neredeyse yarısı $(\% 46,3) 16$ yıl ve üstü kıdeme sahiptir. Katılımcıların \%67,8’i kadın ve \%31,3'ü erkektir. Katılımcıların \%56'sı evlidir. Gelir düzeyi açısından dengeli bir dağılım söz konusudur. Katılımcıların çoğu $(\% 68,7)$ özel sektörde görev yapmaktadır. Lisans mezunları çoğunluktadır $(\% 54,7)$. Ayrıca katılımcıların \%18,2'si yaşam koçluğu hizmeti almışken \%81,8'i almamıştır.

Veri toplama aracı olarak araştırmacılar tarafından uyarlanan Yaşam Koçluğuna İlişkin Tutum Ölçeği ile kişisel bilgileri ve yaşam koçluğuna ilişkin görüşlerin toplanmasını hedefleyen Yaşam Koçluğu ile İlgili Görüşler Anketi kullanılmıştır. Dursun, Alnıaçık ve Kabadayı (2013) tarafından geliştirilen Tüketici Karar Verme Tarzları Ölçeği, yaşam koçluğuna uyarlanmış ve 16 maddelik 5'li likert tipi bir ölçek oluşturulmuştur. 1: kesinlikle katılmıyorum, 2: kat1lmıyorum, 3: orta düzeyde kat1lıyorum, 4: kat1liyorum, 5: kesinlikle katılıyorum anlamına gelmektedir. Ardından ölçek ile ilgili uzman görüşü alınmış ve bu görüş doğrultusunda ölçeğe 2 madde daha eklenmiştir. 18 maddelik ölçeğin pilot uygulaması için 102 kişiden veri toplanmıştır. Pilot uygulamada verilere Croanbach alfa güvenirlik testi ile faktör analizi uygulanmıştır. Bu analiz sonuçlarına bulgular bölümünde yer verilmiştir. Test sonuçlarına göre ölçek maddeleri 14'e düşmüştür. Ölçek, iki boyuttan oluşmaktadır. Boyutlar kalite ve popülerlik olarak isimlendirilmiştir. Boyutlara ait güvenirlik katsayıları ,803 ve ,808'dir. Analizler sonunda ölçeğin geçerli ve güvenilir olduğuna karar verilmiştir. İkinci veri toplama aracı olan ankette ise 9 soru katılımcıların demografik bilgileriyle ilgiliyken, yaşam koçluğuyla ilgili görüşlere ait 14 soru bulunmaktadır. 14 anket sorusu önceki ölçekte olduğu gibi 5'li likert tipindedir.

Veriler araştırmacı tarafından internet üzerinden toplanmıştır. Potansiyel katılımcı kitlesi belirlenmiş ve sosyal medya üzerinden çalışmayı tanıtan bir yazı ile veri toplama araçları online olarak paylaşılmıştır. 214 kişiden dönüş alınmıştır. Veri analizinde ilk olarak pilot uygulama sonuçlarına yer verilmiştir. Veri toplama araçlarından biri olan ölçeğin geçerlilik ve güvenirliğini hesaplamak için faktör analizi ile Croanbach alfa analizi yapılmıştır. Veri 
toplama aracının geçerli ve güvenilir olduğu tespit edildikten sonra veri toplama aşamasına geçilmiş ve 214 kişilik örneklemden toplanan veriler analize dahil edilmiştir. Verilerin analizinde örneklem büyüklüğü $(n=214)$ yeterli olduğu için parametrik testlerden yararlanılmıştır. Yüzde, frekans gibi betimsel istatistikler ile t test ve ANOVA gibi fark istatistikleri veri analizinde kullanılan testlerdir. Elde edilen veriler, SPSS 19.0 paket programı aracılığ

\section{Bulgular}

\subsection{Pilot Analiz, Sonuçlart}

Verilerin toplanması ve veri analizine geçilmeden önce ölçme aracının geçerlilik ve güvenirliğini test etmek adına esas örneklemin dışında 102 katılımcıdan oluşan bir grup ile pilot uygulama yapılmıştır.

Veri toplama aracının yapı geçerliğini test edebilmek amacıyla keşfedici faktör analizi uygulanmıştır. Faktör analizine geçilmeden önce KMO ve Barlett's testlerinin sonuçları incelenmiştir (Tablo 2.a). KMO testi maddelerin faktör analizi için uygunluğunu gösteren bir testtir ve 1'e yakın olması maddelerin analiz için uygun olduğunu ,5'in altına düşmesi ise uygun olmadığını gösterir. Bu analizde KMO ,736 olarak hesaplanmıştır. Veriler faktör analizi için uygundur. Barlett's küresellik testi ise maddelerin arasındaki korelasyonu gösterir. Faktör analizine devam edebilmek için bu testin anlamlı çıkması beklenir. Barlett's testi bu veri toplama aracı için anlamlı $(\mathrm{p}<, 05)$ çıkmıştır.

Tablo 1a. KMO ve Barlett's Test Sonuçları Tablosu KMO ve Bartlett's Testi

\begin{tabular}{|c|c|c|}
\hline \multicolumn{2}{|c|}{ Kaiser-Meyer-Olkin } & ,736 \\
\hline \multicolumn{3}{|c|}{ Örneklem Yeterliliği Testi } \\
\hline Bartlett's & Yaklaşık Ki-Kare & 732,395 \\
\hline \multicolumn{3}{|c|}{ Küresellik Testi Değ. } \\
\hline & SD. & 153 \\
\hline & Anlamlılık Düzeyi &, 000 \\
\hline
\end{tabular}

Faktör analizinde yöntem olarak temel bileşenler analizi seçilmiştir. Öz değerler incelendiğinde (Tablo 2.b) 1'den büyük 5 faktörün olduğu görülmekle birlikte faktör yükleri incelendiğinde maddelerin genellikle 2 faktör altında toplanabileceği görülmüştür (Tablo 3). Veriler 2 faktöre zorlandığında 8., 12. ve 18. maddeler hariç uygun bir model elde edilmiştir. 
8. ve 18. maddeler her iki faktörü birden doldurmakta, 12. madde ise faktör yükü açısından her iki faktörü de dolduramamaktadır (faktör yük değeri <,3). Bu nedenle iki soru da analiz dışı bırakılmıştır. Kalan ölçek 15 maddeli, 2 faktörlü bir ölçek olmuştur. 2 faktörlü model varyansın yaklaşık \%40,5'ini $(24,99+15,44)$ açıklamaktadır. Bu çalışma için uygun bir orandir.

Tablo 2b. Öz Değerler Tablosu

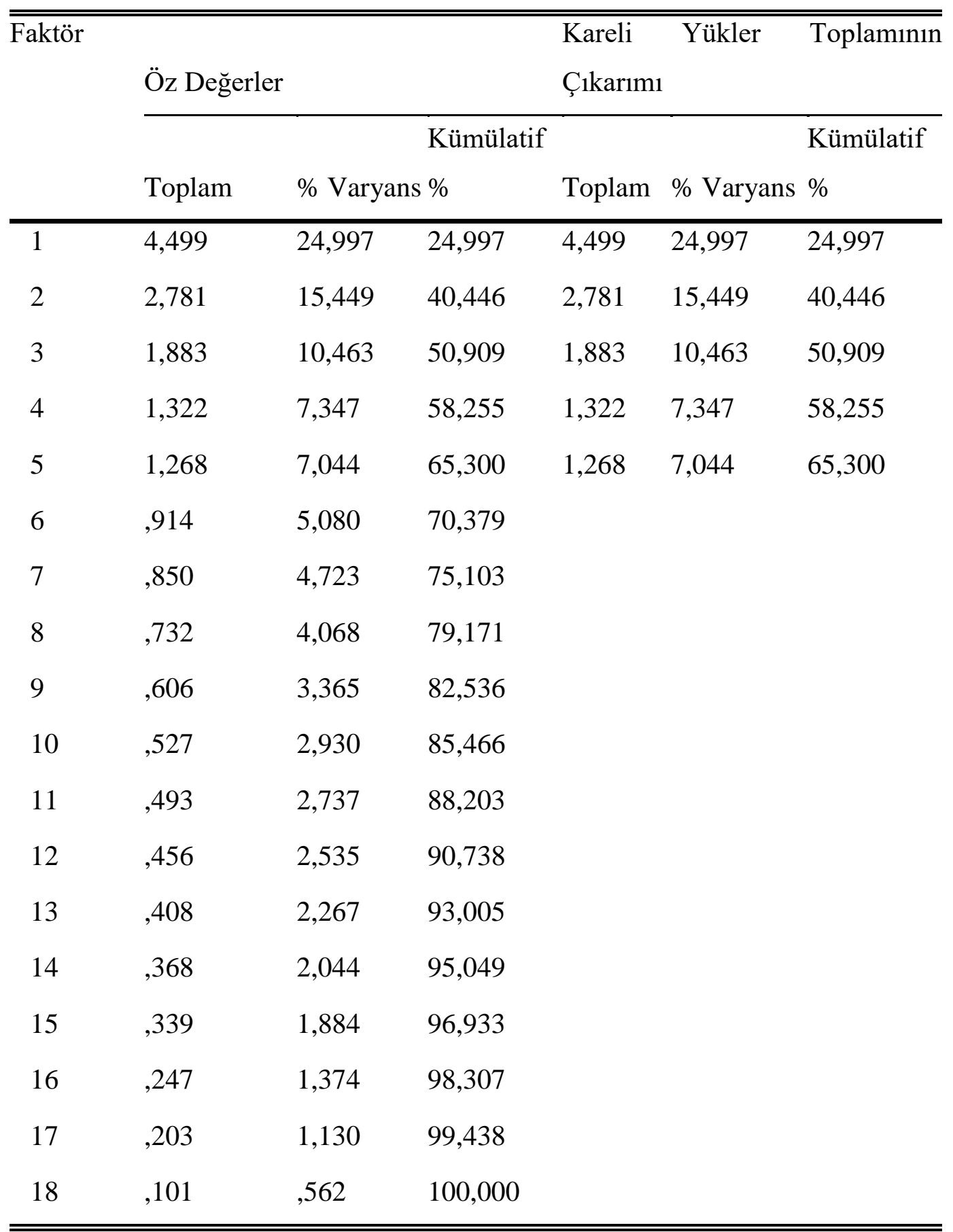


Tablo 3. 5 Faktörde Faktör Yükleri

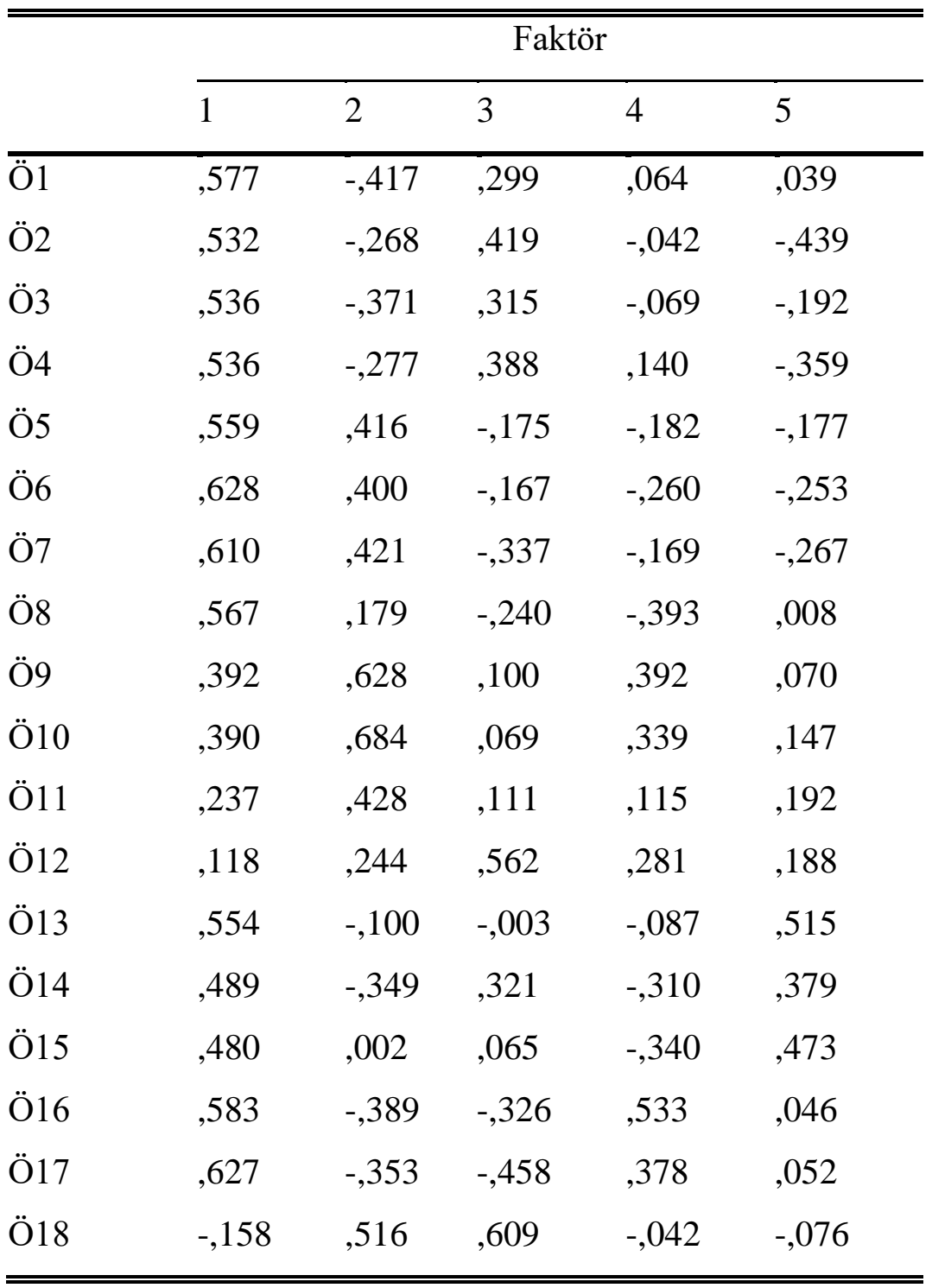

Tablo 4'te ölçeğin son haline ilişkin faktör yükleri sunulmuştur. Buna göre; 1, 2, 3, 4, 13, 14, 15, 16, ve 17. maddeler ilk faktöre $5,6,7,9,10$ ve 11 . maddeler ikinci faktöre aittir. İlk boyuttaki maddeler yaşam koçluğu ile kalite üzerine odaklandığından "kalite boyutu" adı verilirken, ikinci boyuta "popülerlik boyutu” adı verilmiştir. 
Tablo 4. 2 Faktörde Faktör Yükleri

\begin{tabular}{lll}
\hline \hline & \multicolumn{2}{c}{ Faktör } \\
\cline { 2 - 3 } & 1 & 2 \\
\hline Ö1 &, 712 &,- 012 \\
Ö2 &, 589 &, 085 \\
Ö3 &, 652 &, 003 \\
Ö4 &, 598 &, 079 \\
Ö5 &, 220 &, 661 \\
Ö6 &, 286 &, 687 \\
Ö7 &, 259 &, 694 \\
Ö8 &, 362 &, 471 \\
Ö9 &,- 038 &, 739 \\
Ö10 &,- 072 &, 784 \\
Ö11 &,- 050 &, 486 \\
Ö12 &,- 043 &, 268 \\
Ö13 &, 512 &, 235 \\
Ö14 &, 600 &,- 007 \\
Ö15 &, 393 &, 276 \\
Ö16 &, 701 &, 015 \\
Ö17 &, 716 &, 070 \\
Ö18 &,- 425 &, 332 \\
\hline \hline
\end{tabular}

Faktör analizinden sonra 15 maddelik ve iki boyutlu ölçeğe Cranboch alfa güvenirlik analizi uygulanmıştır. Cronbach alfa güvenirlik katsayısı ,806 bulunmuştur (Tablo 5).

Tablo 2. Birinci Güvenirlik Analizi

\begin{tabular}{ll}
\hline \hline Cronbach's Alpha & İfade Sayıs1 \\
\hline, 806 & 15 \\
\hline \hline
\end{tabular}

Maddeler tek tek incelendiğinde 11. Maddenin güvenirliği düşürdüğü ve ölçeğe bir katk1 sağlamadığı görülmüştür (Tablo 6). Bu nedenle 11. Madde de analizden çıkarılmıştır. 
Tablo 3. Madde Güvenirlikleri

\begin{tabular}{ccccc}
\hline \hline & & Madde & Düzeltilmiş & \\
& Madde Silme & Silme & Madde- & Madde Silme \\
& Ölçek & Ölçek & Toplam & Cronbach \\
& Ortalamas1 & Varyans1 & Korelasyon & Alpha Değeri \\
\hline Ö1 & 41,8235 & 55,315 &, 471 &, 791 \\
Ö2 & 41,5490 & 57,577 &, 424 &, 796 \\
Ö3 & 41,5882 & 56,542 &, 412 &, 796 \\
Ö4 & 41,7843 & 56,567 &, 430 &, 795 \\
Ö5 & 43,8529 & 54,404 &, 471 &, 791 \\
Ö6 & 43,9314 & 53,292 &, 526 &, 787 \\
Ö7 & 44,0490 & 54,423 &, 481 &, 790 \\
Ö9 & 44,6471 & 57,854 &, 342 &, 800 \\
Ö10 & 44,7353 & 58,276 &, 347 &, 800 \\
Ö11 & 44,1176 & 58,501 &, 187 &, 814 \\
Ö13 & 42,8725 & 53,479 &, 475 &, 791 \\
Ö14 & 41,9706 & 55,534 &, 386 &, 798 \\
Ö15 & 42,9902 & 55,198 &, 378 &, 799 \\
Ö16 & 42,5882 & 54,720 &, 462 &, 792 \\
Ö17 & 42,7353 & 54,117 &, 504 &, 789 \\
\hline \hline & & & & \\
\hline
\end{tabular}

Ölçeğin son hali 14 maddeli ,814 güvenirlik katsayısına sahip 2 boyutlu bir ölçektir. 1, 2, $3,4,13,14,15,16$ ve 17 . maddeler kalite boyutuna 5, 6, 7, 9 ve 10 . maddeler popülerlik boyutuna aittir. Son güvenirlik analizi sonuçları ölçeğin tamamı ve ayrı ayrı boyutlar için Tablo 7, Tablo 8 ve Tablo 9'da sunulmuştur. Sonuç olarak; geçerli ve güvenilir bir ölçek elde edilmiştir.

Tablo 4. Ölçek Güvenirliği

\begin{tabular}{ll}
\hline \hline Cronbach's Alpha İfade Sayıs1 \\
\hline, 814 & 14 \\
\hline \hline
\end{tabular}

Tablo 5. Kalite Boyutu için Güvenirlik

\begin{tabular}{ll}
\hline \hline Cronbach's Alpha & İfade Sayıs1 \\
\hline, 803 & 9 \\
\hline \hline
\end{tabular}


Tablo 6. Popülerlik Boyutu için Güvenirlik

\begin{tabular}{l}
\hline$\overline{\text { Cronbach's Alpha İfade Say1s1 }}$ \\
\hline \hline, 808 \\
\hline
\end{tabular}

\subsection{Bulgular}

Katılımcıların yaşam koçluğuna ilişkin görüş ve tutumları ne düzeydedir sorusuna cevap olarak yaşam koçluğuna ilişkin tutumlar ölçeğine ait sonuçlar Tablo 10'da sunulmuştur.

Tablo 7. Yaşam Koçluğuyla İlgili Tutumlar

\begin{tabular}{|c|c|c|c|c|c|}
\hline & $\bar{N}$ & "Minimum & Maximum & Ortalama & Ptd. Sapma \\
\hline Kalite & 214 & 1,00 & 5,00 & 3,9881 & ,57137 \\
\hline Popülerlik & 214 & 1,00 & 5,00 & 1,9121 & ,74136 \\
\hline
\end{tabular}

Tablo 10'da görüleceği üzere katılımcılar için kalite oldukça önemli bir değişken iken $(M=3,98)$ yaşam koçluğunun moda olması, başkalarının ilgisini çekmek gibi değişkenler tüketiciler için düşük önem teşkil etmektedir $(M=1,91)$. Yaşam koçluğuna ilişkin tutumların ortalama değerlerine ilişkin veriler ise Tablo 11 'de sunulmuştur.

Tablo 8. Yaşam Koçluğu Hizmetine İlişkin Tutumlar

\begin{tabular}{lr}
\hline \hline Maddeler & Std. \\
& OrtalamaSapma
\end{tabular}

\begin{tabular}{lrr}
\hline Yaşam koçundan arkadaşım olmasını beklerim & 2,7150 & 1,25525 \\
Yaşam koçundan danışmanım olmasını beklerim & 3,7009 & 1,13597 \\
Yaşam koçundan mentorluk beklerim & 3,6121 & 1,05441 \\
Yaşam koçundan rehberlik beklerim & 4,0187 & 1,00217 \\
Yaşam koçu hizmetini almak için internet araştırması3,8972 & 1,06972 \\
yaparım &
\end{tabular}

Yaşam koçluğu hizmetini arkadaş tavsiyesi üzerine3,3364 1,06099 alırım

Yaşam koçu hizmetini almak için koçluk örgütlerine2,8692 1,13489 başvururum 
Yaşam koçluğu hizmeti alırken seans sıklığını göz3,5327 ,98169 önüne alırım

Yaşam koçluğu hizmeti alırken lokasyon değişkenini3,6121 1,04096 önemserim

Yaşam koçluğu hizmeti alırken koçun eğitim4,3551 ,90125 durumunu önemserim

Yaşam koçluğu hizmeti alırken koçun tecrübesini4,5187 ,80324 önemserim

Yaşam koçluğu hizmeti alırken koçun motivasyonunu4,5421 ,77859 önemserim

Yaşam koçluğuna ayıracağım bütçe benim için4,2150 ,90930 önemlidir Yaşam koçluğu hizmetine ayıracağım süre benim için4,2617 ,94284 önemlidir

Tablo 11'de görüleceği üzere yaşam koçundan en çok rehberlik yapması beklenmektedir $(\mathrm{M}=4,01)$. Rehberliği, danışmanlık $(\mathrm{M}=3,70)$, mentorluk $(\mathrm{M}=3,61)$ ve arkadaşlık $(\mathrm{M}=2,71)$ değişkenleri izlemiştir. En az tercih edilen arkadaşlık değişkeni olmuştur. Katılımcılar yaşam koçluğu almak için araştırma yaparken en fazla internet kaynağını tercih ettiklerini $(M=3,89)$ arkadaş tavsiyesini orta düzeyde $(\mathrm{M}=3,33)$ koçluk örgütlerini ise daha düşük düzeyde $(\mathrm{M}=2,86)$ tercih ettiklerini belirtmişlerdir. Katılımcılar yaşam koçluğu hizmeti almada koçluk yapacak kişinin tecrübesini, motivasyonunu ve eğitim düzeyini çok yüksek düzeyde önemsemektedir ( $M=4,54, M=4,51, M=4,35)$. Lokasyon değişkeni ise orta düzeyde önemli bulunmaktadır. Ayrıca koçluk hizmetine ayrılacak süre ile bütçe de katılımcılar tarafından yüksek düzeyde önemli olarak nitelendirilmiştir ( $M=4,26, M=4,21)$.

Cinsiyet değişkenine göre yaşam koçluğuyla ilgili algıların farklılaşıp farklılaşmadığını belirlemek için ölçek puanları üzerinden bağımsız örneklemler t testi uygulanmıştır. Gruplara ait ortalamalar Tablo 12'de sunulmuştur. 
Tablo 9. Cinsiyet Değişkenine İlişkin Ortalamalar

\begin{tabular}{|c|c|c|c|c|c|c|}
\hline \multicolumn{7}{|c|}{ CINSIIYET } \\
\hline & & & $\mathrm{N}$ & Ortalama & Std. Sapma & Std. Hata Ort. \\
\hline \multirow[t]{2}{*}{ Kalite } & \multirow{2}{*}{$\mathrm{d}$} & Kadın & 147 & 4,0174 &, 53219 & ,04389 \\
\hline & & Erkek & 67 & 3,9237 & ,64881 & ,07926 \\
\hline \multirow[t]{2}{*}{ Popülerlik } & \multirow{2}{*}{$\mathrm{d}$} & Kadın & 147 & 1,8667 & ,74845 & ,06173 \\
\hline & & Erkek & 67 & 2,0119 & ,72101 & ,08809 \\
\hline
\end{tabular}

Kadın katılımcıların kalite boyutuyla ilgili ortalamaları $(\mathrm{M}=4,01)$ erkek katılımcılara $(M=3,972)$ nazaran yüksektir. Popülerlik boyutunda ise tersine erkek kat1lımcıların ortalamaları $(\mathrm{M}=2,01)$ kadın katılımcılardan $(\mathrm{M}=1,86)$ yüksek çıkmıştır. Ancak bu farklar istatistiksel olarak anlamlı değildir $(p=, 267 ; p=, 184)$.

Katılımcıların yaşam koçluğuna ilişkin algılarının gelir düzeyine göre farklılaşıp farklılaşmadığını saptamak için ANOVA testi yapılmıştır. Gruplara ait ortalamalar için ANOVA testi sonuçları Tablo 13'te sunulmuştur.

Tablo 13. Gelir Düzeyi Değişkenine Göre Ortalamalar

\begin{tabular}{llllll}
\hline \hline & & & & & \\
& & & & Std. & \\
\hline Kalite & 3000 altı & 43 & 3,9147 &, 54208 &, 08267 \\
& $3001-5000$ & 72 & 3,9660 &, 69543 &, 08196 \\
& $5001-7000$ & 38 & 3,8977 &, 45511 &, 07383 \\
& $7001-9000$ & 25 & 4,0800 &, 50768 &, 10154 \\
& 9001 üstü & 36 & 4,1512 &, 45554 &, 07592 \\
& Total & 214 & 3,9881 &, 57137 &, 03906 \\
\hline Popülerlik & 3000 alt1 & 43 & 1,9116 &, 81451 &, 12421 \\
& $3001-5000$ & 72 & 1,7500 &, 73062 &, 08610 \\
& $5001-7000$ & 38 & 1,9474 &, 75076 &, 12179 \\
& $7001-9000$ & 25 & 2,1440 &, 65452 &, 13090 \\
& 9001 üstü & 36 & 2,0389 &, 68255 &, 11376 \\
& Total & 214 & 1,9121 &, 74136 &, 05068 \\
\hline \hline
\end{tabular}

Tablo 13'te görüleceği üzere kalite ortalamasıyla ilgili olarak genel anlamda gelir düzeyi arttıkça kalite beklentisi artmaktadır. Aynı şekilde gelir düzeyiyle artan bir popülerlik artışı örüntüsü de söz konusudur. 9001 TL ve daha çok gelir düzeyi olanlar diğer gruplara nazaran daha yüksek kalite ve popülerlik beklentisi içerisindedir. 
Tablo 14. Gelir Düzeyine Göre ANOVA Sonuçları

\begin{tabular}{lllllll}
\hline \hline & & Kareler & \multicolumn{3}{c}{ Kareler } \\
& Toplamı & Sd. & Ortalaması F & Sig. \\
\hline Kalite & Gruplar Arası & 1,747 & 4 &, 437 & 1,346 &, 254 \\
& Grup İçi & 67,791 & 209 &, 324 & & \\
& Toplam & 69,537 & 213 & & & \\
\hline Popülerlik & Gruplar Arası & 3,862 & 4 &, 966 & 1,783 &, 134 \\
& Grup İçi & 113,206 & 209 &, 542 & & \\
& Toplam & 117,068 & 213 & & & \\
\hline \hline
\end{tabular}

Öte yandan Tablo 14'e bakıldığında gelir düzeyi açısından gruplar arası farkın istatistiksel olarak anlamlı olmadığı görülecektir ( $p=, 254 ; p=, 134)$. Gelir düzeyi yaşam koçluğuna ilişkin tutumu farklılaştırmada anlamlı bir değişken değildir.

Daha önce yaşam koçluğu alıp almama değişkenine göre yaşam koçluğuyla ilgili algıların farklılaşıp farklılaşmadığını belirlemek için ölçek puanları üzerinden bağımsız örneklemler t testi uygulanmıştır.

Tablo 10. Yaşam Koçluğu Alma Durumuna Göre Ortalamalar

\begin{tabular}{|c|c|c|c|c|c|}
\hline & \multicolumn{5}{|l|}{ Koçluk Hizmeti } \\
\hline & Alma Durumu & $\mathrm{N}$ & Ort. & Std. Sapma & Std. Hata Ort \\
\hline \multirow[t]{2}{*}{$\overline{\text { Kalite }}$} & EVET & 39 & 4,1795 & ,33684 & ,05394 \\
\hline & HAYIR & 175 & 3,9454 & 60400 & 04566 \\
\hline \multirow[t]{2}{*}{ Popülerlik } & EVET & 39 & 1,7641 & ,54844 & ,08782 \\
\hline & HAYIR & 175 & 1,9451 & ,77531 & 05861 \\
\hline
\end{tabular}

Tablo 16'da görüleceği üzere daha önce yaşam koçluğu alan katılımcıların kalite beklentisi $(M=4,17)$ almayanlara nazaran $(M=3,94)$ daha yüksekken, popülerlik ile ilgili ortalamalarda koçluk hizmeti almayanların $(M=1,94)$ alanlara göre $(M=1,76)$ daha yüksek bir beklenti içinde oldukları görülmektedir. T testi sonuçlarına göre daha önce yaşam koçluğu almış ya da almamış olma değişkeni popülerlik algısını farklılaştırmazken $(p=, 168)$ kalite algısı anlamlı derecede daha önce yaşam koçluğu hizmeti almış olan katılımcılar lehine farklılaşmaktadır $(\mathrm{p}<, 05)$. 


\section{Sonuç}

Tüketicilerin yaşam koçluğuna ilişkin görüş ve tutumlarını ortaya çıkarmayı amaçlayan bu çalışmanın bulgularına göre, koçluk seçiminde katılımcılar için kalite oldukça önemli bir değişken iken yaşam koçluğunun moda olması, başkalarının ilgisini çekmek gibi faktörler tüketiciler için yüksek önem taşımamaktadır. Başkalarını etkilemek ya da moda olduğu için yaşam koçluğuna başvurmak katılımcılar için etkili bir faktör değildir. Bu noktadan hareketle katılımcıların başkalarından çok kendi gelişimleriyle ilgilenmeyi tercih ettikleri söylenebilir.

Yaşam koçundan en fazla rehberlik yapması beklenmektedir. Rehberliği, danışmanlık, mentorluk ve arkadaşlık değişkenleri izlemiştir. En az tercih edilen arkadaşlık değişkeni olmuştur. $\mathrm{Bu}$ örneklemdeki katılımcıların yaşam koçundan arkadaşlık ilişkisinden ziyade çözemedikleri konular hakkında yol göstericilik bekledikleri söylenebilir. Akın ve Ulukök (2017) benzer şekilde koçların en önemli görevlerinden birinin yönlendirme olduğunu tespit etmişlerdir. Bunun yanında motivasyon sağlama, iletişimi geliştirme ve stres azaltma da koçtan beklenenler arasındadır. Kalçık (2018) da koçluk mesleğini iyi bir yol arkadaşı ve destekçi olarak tanımlamıştır.

Katılımcılar yaşam koçluğu almak üzere yaptıkları araştırmalar için en fazla internet kaynağını tercih ettiklerini, arkadaş tavsiyesini orta düzeyde, koçluk örgütlerini ise daha düşük düzeyde tercih ettiklerini belirtmişlerdir. İnternet tüketicilerin satın alma davranışlarında gelişen ve yaygınlaşan teknolojiyle birlikte en önemli araç haline gelmiştir. $\mathrm{Bu}$ sebeple katılımcılar tarafından yoğun olarak tercih edilmesi olağan bir sonuçtur. Koçluk örgütlerinin az tercih edilme nedeni yeterince bilinmiyor olmaları olabilir. $\mathrm{Bu}$ sonuç doğrultusunda, koçluk örgütlerinin üyelerinin de lehine sonuçlanacak şekilde bilinirliklerini arttırmaya yönelik çabalara girmelerinin faydalı olacağı görülmektedir.

Katılımcılar yaşam koçluğu hizmeti almada koçluk yapacak kişinin tecrübesini, motivasyonunu ve eğitim düzeyini çok yüksek derecede önemsemektedir. Lokasyon değişkeni ise orta düzeyde önemli bulunmaktadır. Ayrıca koçluk hizmetine ayrılacak süre ile bütçe de katılımcılar tarafından önemli faktörler olarak nitelendirilmiştir. Bu bulguyla ilişkili bir biçimde, önemli zaman ve maddi kaynakların ayrılmasını gerektiren bu süreçte, yüksek kalite beklentisi ile koçluk yapacak kişinin tecrübesi, motivasyonu ve eğitim düzeyi de önemsenmektedir. Dolayısı ile bu sektörde faaliyet göstermekte olan kişi ve kurumların, tüketicilerin zihninde güçlü bir konumlandırmaya sahip olabilmeleri için eğitim düzeyi ve tecrübe açısından kendilerini donatmaları en temel başarı faktörlerinden biri olarak ortaya çıkmaktadır. 
Bulgulara göre kadın katılımcıların kalite beklentisi, erkek katılımcıların ise popülerlik ile ilgili beklentileri daha yüksektir; ancak gruplar arası farklar istatistiksel olarak anlamlı değildir. Akçil (2012) okul yöneticilerinin koçluk becerilerini değerlendirdiği çalışmasında, cinsiyeti farklı bir biçimde ele almış ve koçluk becerileri üzerindeki etkisini incelemiştir. Sonuçlara göre cinsiyet koçluk becerilerini etkileyen bir değişken değildir. İki çalışmanın sonucu bir arada değerlendirildiğinde cinsiyetin hem koçluk ile ilgili algıları hem de koçluk becerisini farklılaştırmada anlamlı bir değişken olmadığı söylenebilir.

Genel olarak katılımcıların gelir düzeyi arttıkça kalite beklentileri de artmaktadır. Aynı şekilde gelir düzeyiyle artan bir popülerlik beklentisi örüntüsü de söz konusudur. 9001 TL ve daha çok geliri olanlar, diğer gruplara nazaran daha yüksek kalite ve popülerlik beklentisi içerisindedir. Ancak gelir düzeyi açısından gruplar arası farkın istatistiksel olarak anlamlı olmadığı tespit edilmiştir. Buna karşın, farklı gelir düzeylerine sahip tüketicilerin tutumlarında görülen farklılık ve bilhassa yüksek gelir gruplarında artan popülerlik beklentisi, gelir düzeyinin hedef kitle beklentilerinin tespitine ilişkin çalışmalarda dikkate alınması gerektiğini göstermiştir.

Bulgulara göre daha önce yaşam koçluğu alan katılımcıların kalite beklentisi, almayanlara nazaran daha yüksekken popülerlik ile ilgili ortalamalarda daha önce koçluk hizmeti almayanların alanlara göre daha yüksek beklenti içinde oldukları görülmüştür. Daha önce yaşam koçluğu almış ya da almamış olma değişkeni popülerlik algısını farklılaştırmazken, kalite algısı anlamlı derecede daha önce yaşam koçluğu hizmeti almış olan katılımcılar lehine farklılaşmaktadır. Daha önce koçluk hizmeti almış olan kişiler, yaşadıkları olumlu ya da olumsuz tecrübeler nedeniyle kalite değişkeninin çok önemli olduğunu süreç içerisinde daha iyi anlamış olabilirler. Benzer şekilde koçluk hizmetinden memnun kalıp, iyi bir rehberlik aldıkları için de kaliteyi ön planda tutuyor olmaları söz konusu olabilir. Dolayısı ile daha önce koçluk hizmeti alan kişilerin, daha yüksek kalite beklentileri ile hareket ediyor olmalarından dolayı algılanan hizmet kalitesi ve hizmetten alınan tatmin açısından daha hassas bir kitle olarak değerlendirilmeleri söz konusu olabilir.

$\mathrm{Bu}$ araştırma ile elde edilen bulgular ışı̆̆ında, giderek büyüyen koçluk hizmetleri pazarının dinamiklerinin ve tüketici tercihlerini etkileyen faktörlerin daha iyi anlaşılabilmesi için farklı çalışmalar yapılması gerekliliği de bir kere daha ortaya çıkmaktadır. Literatürde yaşam koçluğuna ilişkin tutum ve tercihlere dair bir ankete rastlanmamaktadır. Dolayısı ile bu çalışma kapsamında önceki çalışmalardan uyarlanan anket ile literatürdeki bu açığın kapatılması hedeflenmiş, bu alanda yapılacak olan sonraki çalışmalarda kullanılabilecek bir araç ortaya koyulmuştur. Bu çalışmanın kısıtlarından biri sınırlı örneklem sayısı ve örneklem 
dağılımıdır. Farklı nicel çalışmalarda daha geniş bir örnekleme ulaşılarak anket geçerliliği ve güvenilirliğinin doğrulanması ve sonuçların genellenebilirliğinin sağlanması literatüre katkı sağlayacaktır. Öte yandan, koçluk hizmetlerinde algılanan hizmet kalitesini etkileyen faktörlerin detaylı bir şekilde değerlendirilebilmesi için bundan sonraki çalışmalarda nitel araştırma yöntemlerinin kullanılması da önerilmektedir. Nitel yöntemler ile tüketicilerin bilhassa yaşam koçluğu gibi kişisel hayatlarını yakından etkileyen bir koçluk dalındaki tercihlerini daha detaylı bir biçimde ortaya koymak mümkün olabilecektir. 


\section{KAYNAKÇA}

Akçil, Mustafa. "İlköğretim Okul Yöneticilerinin Koçluk Rollerinin Değerlendirilmesi.” Yüksek Lisans Tezi, Afyon Kocatepe Üniversitesi Sosyal Bilimler Enstitüsü, 2012.

Akın, Adnan ve Esra Ulukök. "Koçluk Yaklaşımı ile İşgören Geliştirme.” Kırıkkale Üniversitesi Sosyal Bilimler Dergisi, 7(2), (2017): 279-300.

Aydar, Neslihan. "Bir Eğitim Tekniği Olarak Koçluk.” Yüksek Lisans Tezi, Sakarya Ｕ̈niversitesi Sosyal Bilimler Enstitüsü, 1999.

Barutçu, E. Ve Özbay Ö. (2013). Koçluk Yaklaşımının Yönetici Ve İş Gören Üzerine Etkilerine İlişkin Bir Araştırma. Kilis 7 Aralık Üniversitesi İktisadi Ve İdari Bilimler Fakültesi Akademik Araştırmalar Ve Çalışmalar Dergisi, 1, 47-62.

Burke, Sarah ve Karen.M. Collins. "Gender Differences in Leadership Styles and Management Skills." Women in Management Review, 16(5), 1999: 244-257.

Büngül, B. “Öğretmenlikte Uygulanan Mentorluğun Öğretmen Koçluğu ile ～Desteklenmesi.” Yüksek Lisans Tezi, Çanakkale Onsekiz Mart Üniversitesi Eğitim Bilimleri Enstitüsü, 2015.

Çakar, B. A. (2011). İlköğretim Denetçilerinin Koçluk Becerilerini Sergileme Düzeylerine İlişkin Öğretmen Görüşleri. Yüksek Lisans Tezi. Çanakkale Onsekiz Mart Üniversitesi Sosyal Bilimler Enstitüsü, Çanakkale.

Çatalbaş, Erkan. "8. Sınıf Öğrencilerinin Ders Başarısında Eğitim Koçluğunun Etkileri." Yüksek Lisans Tezi, İstanbul Aydın Üniversitesi Sosyal Bilimler Enstitüsü, 2016.

Çavuşoğlu, G. Ö. "Kurumlarda Yüksek Performans için Rehberlik Temelli Öğrenme ve Gelişim Süreçleri ve Bir Model Önerisi.” Yüksek Lisans Tezi. Maltepe Üniversitesi, Sosyal Bilimler Enstitüsü, İstanbul.

Çetin, E. "Öğrenci Görüşlerine Göre Lise Son Sınıf Rehber Öğretmenlerinin Koçluk Beceri Düzeyleri Kocaeli İli Örneği.” Yüksek Lisans Tezi, Sakarya Üniversitesi Eğitim Bilimleri Enstitüsü, 2015.

Dağ, F. "Leadership in Education In Terms of Coaching.” Yüksek Lisans Tezi, Yeditepe Üniversitesi Sosyal Bilimler Enstitüsü. 2010.

Dursun, İnci, Ümit Alnıaçık ve Ebru Tümer Kabadayı. "Tüketici Karar Verme Tarzları Ölçeği: Yapısı ve Boyutları." Uluslararası Yönetim İktisat ve İşletme Dergisi, 9(19), 2013: 293-304.

Elgün, Rıza Feridun. "Yöneticilerin Koçluk Uygulamalarının Satış Personelinin İş Tatmini Üzerindeki Etkileri ve Satış Personeline Yönelik Uygulama.” Yüksek Lisans Tezi, Dumlupınar Üniversitesi Sosyal Bilimler Enstitüsü, 2007.

Eryılmaz, Eda. "Postmodern Dönemin Bireye Yansımaları Açısından Koçluk.” Yüksek Lisans Tezi, Maltepe Üniversitesi Sosyal Bilimler Enstitüsü, 2014.

Gezer, H. "Yönetici Koçluk Davranışının Çalışan Tatminine Etkisi Üzerine Bir Araştırma.” Yüksek Lisans Tezi, Haliç Üniversitesi Sosyal Bilimler Enstitüsü. 2016.

Gökçek, İlke. "Jung’un Sınıflaması Temel Alınarak Oluşturulan Kişilik Boyutlarının ～Eğitici Yöneticiliğe Etkisi.” İstanbul Üniversitesi Sosyal Bilimler Enstitüsü, 2006.

Grant, A. M. (2003a). The İmpact Of Life Coaching On Goal Attainment, Metacognition And Mental Health. Social Behavior \& Personality. 31(3). 253-264.

Grant, A. M., \& Spence, G. B. (2010). Using Coaching And Positive Psychology To Promote A Flourishing Workforce: A Model Of Goal-Striving And Mental Health. (P. 175-188). Oxford University Press.

Grant, A., Cavanagh M., Kemp, T. (2005). Theory, Research And Practice From The Behavioural Sciences: Evidence-Based Coaching. (1). Bowen Hills Qld, Australia: Australian Academic Press.

Grant, A.M. (2003b). Keeping Up With The Cheese! Research As A Foundation For Professional Coaching Of The Future. Paper Presented At The International Coach

Grant, A.M. And Greene, J. (2003). Coach Yourself : Make Real Change In Your Life. Momentum Books, Pearson Education Limited. USA.

Green, Oades Ve Grant (2006). Cognitive-Behavioral, Solution-Focused Life Coaching: Enhancing Goalstriving, Well-Being, And Hope. The Journal Of Positive Psychology, July 2006; 1(3): 142-149 DOI: 10.1080/17439760600619849

Green, S., Grant, A., \& Rynsaardt, J. (2007). Evidence-Based Life Coaching For Senior High School Students: Building Hardiness And Hope. International Coaching Psychology Review, 2(1), 24-32.

Green,S., Oades, L. G. Grant, A.M. (2005). An Evaluation Of A Life-Coaching Group Program: Initial Findings From A Waitlist Control Study. Evidence-Based Coaching. Grant, A., Cavanagh M., Cavanah, T. Volume 1. 127-140. Bowen Hills Qld, Australia.Australian Academic Press.

Güler, H . (2020). Kadın Dostu Şirketlerin İnsan Kaynakları Uygulamaları . Kapadokya Akademik Bakış , 4 (2), 1-19 . Retrieved From Https://Dergipark.Org.Tr/En/Pub/Car/İssue/58937/836319

ICF Turkey.2021. Erişim Tarihi: 24.01.2021 Erişim Adresi Https://Www.İcfturkey.Org/Kocluk-Hakkinda/Bir$\underline{\text { Koc-Olmak-İcin/ }}$

International Coaching Federation. Erișim tarihi: 4.3.2019 Koçluk.http://www.icfturkey.org, 
Kalçık, F. (2018). Öğrenci Koçluğu Destekli Kuantum Öğrenme Yaklaşımının Fen Bilimleri Dersinde Öğrencilerin Akademik Başarısına Ve Derse Karşı Tutumuna Etkisi. Bartın Üniversitesi Sosyal Bilimler Enstitüsü, Bartın.

Kalçık, Fatih. “Öğrenci Koçluğu Destekli Kuantum Öğrenme Yaklaşımının Fen Bilimleri Dersinde ̈ğrencilerin Akademik Başarısına Ve Derse Karşı Tutumuna Etkisi.” Bartın Üniversitesi Sosyal Bilimler Enstitüsü, 2018.

Kalkavan, Selma. "Farklı Örgütsel Kültürlerde Yönetici Koçluk Davranışının Çalışanların İş Tatmini, Örgütsel Bağlılık Ve Örgütsel Performans Algılarına Etkisi.” Doktora Tezi, İ́stanbul Aydın Üniversitesi Sosyal Bilimler Enstitüsü, 2014.

Knight, J. (2006). Instructional Coaching. School Administrator, 63(4), 36-41.

Mcmanus, Patty. Koçluk. İstanbul: Optimist, 2007.

Mumford, Jeni. Life Coaching For Dummies. West Sussex: Wiley, 2007.

Peterson, David B. ve Marry D. Hicks. Leader as Coach. Minneapolis: Personnel Decisions Inc., 1996.

Poussard, Jale Minibas. Yönetimde Yeni Bir Stil Coaching. İstanbul: Yaylacık, 2004.

REISS, K. (2004), “Coaching Leadership”, Leadership, January/February2004, 34-36.

Talak, K. Koçluk Desteği Alan Çalışanların İş Tatmin Düzeylerinin İncelenmesi. 19 Mayıs Sosyal Bilimler Dergisi, 1(3), 191-204.

Türk Dil Kurumu. Erişim tarihi: 1.3.2019 "Koçluk". http://www.tdk.gov.tr/index.php?option=com_gts\&arama=gts\&guid=TDK.GTS.54e9e725a9a2d0.5637 $\underline{5888}$

Underhill, Brian. O., Kimcee McAnally ve John. J. Koriath. Executive Coaching For Results: The Definitive Guide to Developing Organizational Leaders. New York: Berrett Koehler, 2007.

Wasylyshyn, K. M. (2003). Executive Coaching: An Outcome Study. Consulting Psychology Journal: Practice And Research, 55(2), 94-106.

Yurdakul, K. Koçluk Kültürü. İstanbul: Kariyer, 2010.

Zeus, P. Ve Skiffington, S. (2004). Behavioural Coaching, Mcgraw-Hill, Professional Series, Paperback, P.48. 
EK 1 :

\section{Yaşam Koçluğu ile İlgili Görüşler Anketi}

Sayın Katılımcı,

Bu anket, yüksek lisans tez çalışmam kapsamında siz değerli katılımcıların yaşam koçluğu hizmeti satın alma tercihlerini ölçmek ve değerlendirmek amacıyla hazırlanmıştır. Verdiğiniz bilgiler gerçekleştirilecek olan bilimsel çalışma dahilinde, kişisel bilgileriniz paylaşılmadan değerlendirilecektir.

Ölçek kapsamındaki sorulara verilebilecek cevaplar sırasıyla aşağıdaki gibidir:

1: Kesinlikle Katılmıyorum

2: Katılmıyorum

3: Orta Derecede Katılıyorum

4: Katılıyorum

5: Kesinlikle Katılıyorum

Ankete katıldığınız için teşekkür ederim.

Sinem OCAK

sinemocak@gmail.com

${ }^{*}$ Gerekli

\section{Demografik Bilgiler}

\section{Cinsiyetiniz:}

$\square$ Kadın $\quad \square$ Erkek

2.Yaşınız:

$\square$ 25-34 $\square$ 35-44 $\square$ 45-54 $\square$ 55-64 $\square 65$ ve üstü

3. Medeni durumunuz:
$\square$ Bekar Evli

4. Eğitim durumunuz:

$\square$ İlkokul $\quad \square$ Ortaokul $\square$ Lise $\quad \square$ Lisans $\square$ Yüksek Lisans $\square$ Doktora

5. Çalışma durumunuz:

$\square$ Kamu $\quad \square$ Özel Sektör $\quad \square$ Emekli $\square$ Çalışmıyor

6. Çalışma Süreniz:
$\square$ 0-1 Yil
$\square$ 2-3 Y1l
4-6 Yil
$7-10 Y_{11}$
$11-15$ Y1l
16 Y1l ve üstü

7. Gelir düzeyiniz: 
Ocak, S., Yurdakul, D. / Journal of Yasar University, 2021, 16/62, 835-866

$\square$ 3000も alt1 $\square$ 3001も-5000も aras1 $\square$ 5001も-7000も aras1 $\square$ 7001も-9000も aras1

9001も ve üzeri

8. Daha önce yaşam koçluğu hizmeti aldınız mı?

$\square$ Evet $\quad \square$ Hayır

9. 8. Soruya cevabınız "evet” ise; yaşam koçluğu hizmetinden memnun kaldınız mı?

$\square$ Evet $\quad \square$ Hayır 
Ocak, S., Yurdakul, D. / Journal of Yasar University, 2021, 16/62, 835-866

\section{Ölçek}

Düşük puan katılmadığınızı, yüksek puan ise katıldığınızı göstermektedir.

1: Kesinlikle Katılmryorum

2: Katilmıyorum

3: Orta Derecede Katiliyorum

4: Katiliyorum

5: Kesinlikle Katiliyorum

1. Yaşam koçluğu hizmetinin yüksek kalitede olması benim için çok önemlidir. *

$$
\begin{array}{llllllll} 
& 1 & 2 & 3 & 4 & 5 & \\
\text { Kesinlikle Katılmıorum } & \bigcirc & \bigcirc & \bigcirc & \bigcirc & \bigcirc & \text { Kesinlikle Katllyorum }
\end{array}
$$

2. Aldığım hizmetin kusursuz olmasını isterim. *

$$
\begin{array}{lcccccc} 
& 1 & 2 & 3 & 4 & 5 & \\
\text { Kesinlikle Katılmıorum } & \bigcirc & \bigcirc & \bigcirc & \bigcirc & \bigcirc & \text { Kesinlikle Katllyorum }
\end{array}
$$

3. Genellikle en iyi hizmeti alabilmek için araştırııım. *$$
\begin{array}{lllll}
1 & 2 & 3 & 4 & 5
\end{array}
$$
Kesinlikle Katılmıyorum $\bigcirc \bigcirc \bigcirc \bigcirc \bigcirc$ Kesinlikle Katılıorum

4. Almak istediğim hizmete yönelik standartlarım ve beklentilerim oldukça yüksektir. *

$$
\begin{array}{lccccccc} 
& 1 & 2 & 3 & 4 & 5 & \\
\text { Kesinlikle Katılmıorum } & \bigcirc & \bigcirc & \bigcirc & \bigcirc & \bigcirc & \text { Kesinlikle Katılıyorum }
\end{array}
$$

5. Yaşam koçluğu hizmetini alırken en fazla ücret isteyen koçlarla çalışııım/çalışmak isterim. *
$\begin{array}{lllll}1 & 2 & 3 & 4 & 5\end{array}$
Kesinlikle Katılmıorum $\bigcirc \bigcirc \bigcirc \bigcirc \bigcirc$ Kesinlikle Katllyorum

6. Bir hizmetin bedeli ne kadar yüksekse o kadar kalitelidir. *

Kesinlikle Katılmıyorum $\bigcirc \bigcirc \bigcirc \bigcirc \bigcirc$ Kesinlikle Katılıyorum 
Ocak, S., Yurdakul, D. / Journal of Yasar University, 2021, 16/62, 835-866

7. Ünlü yaşam koçları en iyi hizmeti sunar. *

$\begin{array}{lllll}1 & 2 & 3 & 4 & 5\end{array}$

Kesinlikle Katılmıyorum $\bigcirc \bigcirc \bigcirc \bigcirc \bigcirc$ Kesinlikle Katllyorum

8. En çok tercih edilen yaşam koçlarıyla çalışmak isterim. *

$\begin{array}{llllllll} & 1 & 2 & 3 & 4 & 5 & \\ \text { Kesinlikle Katılmıyorum } & \bigcirc & \bigcirc & \bigcirc & \bigcirc & \bigcirc & \text { Kesinlikle Katılıorum }\end{array}$

9. Moda olduğu için yaşam koçluğu hizmeti alıyorum /almak isterim. *

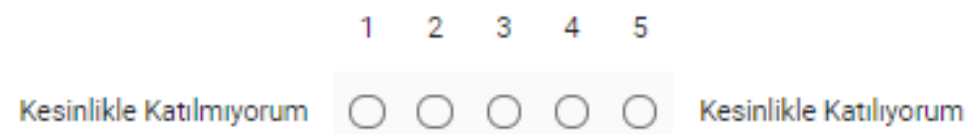

10. Çevremdekilerin dikkatini çekmek için yaşam koçluğu hizmeti alıyorum /almak isterim. *

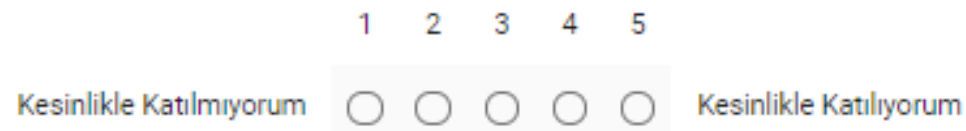

11. Bir hizmeti alırken çok düşünmeden karar veririm. *

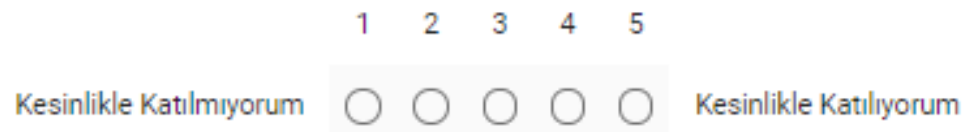

12. Sonradan pişman olduğum satın aldığım hizmetler vardır. *

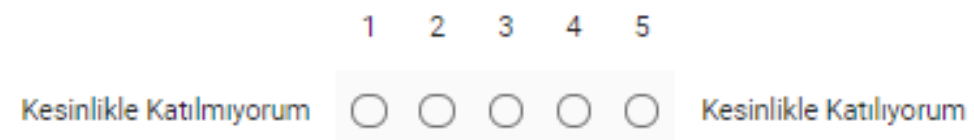

13. Bir kez çalıştığım yaşam koçuyla sürekli çalışmak isterim. *

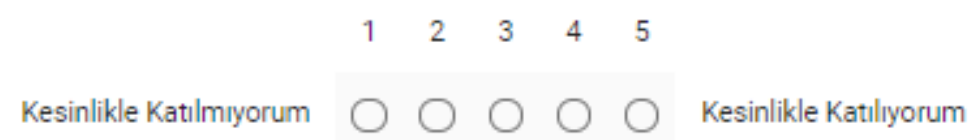

14. Hizmetinden memnun olduğum yaşam koçunu kolay kolay bırakmak istemem. *

$$
\begin{array}{lllll}
1 & 2 & 3 & 4 & 5
\end{array}
$$

Kesinlikle Katılmıorum $\bigcirc \bigcirc \bigcirc \bigcirc \bigcirc$ Kesinlikle Katılıyorum 
Ocak, S., Yurdakul, D. / Journal of Yasar University, 2021, 16/62, 835-866

15. Hangi yaşam koçuyla çalışacağıma karar verirken zorlanırım.

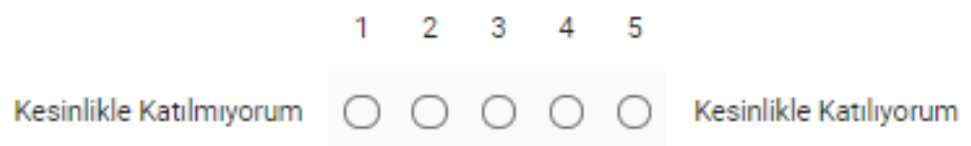

16. Yaşam koçuyla çalışmak faydalıdır. *

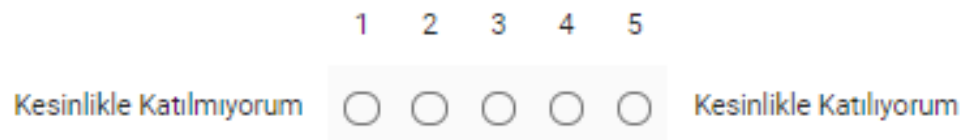

17. Yaşam koçuyla çalışmak hayatı kolaylaştırır. *

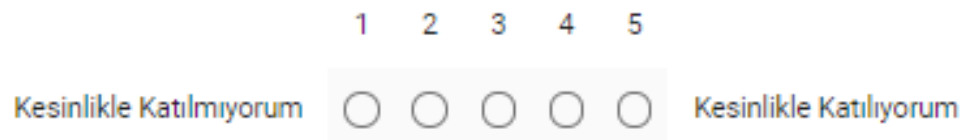

18. Yaşam koçuyla çalışmanın olumlu bir etkisi yoktur. *

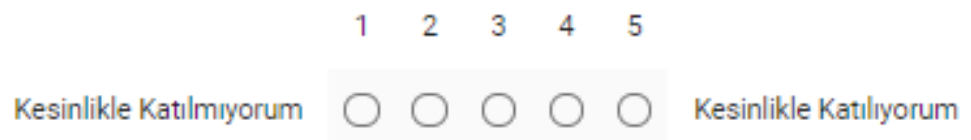

19. Yaşam koçundan arkadaşım olmasını beklerim. *

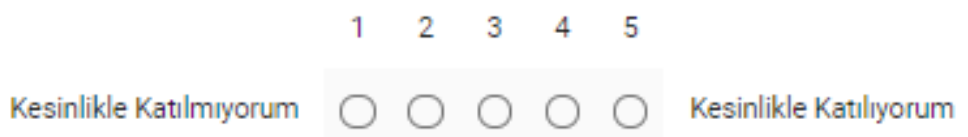

20. Yaşam koçundan danışmanım olmasını beklerim. *

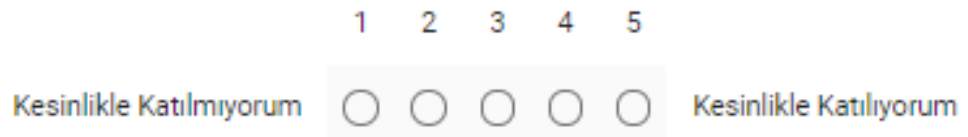

21. Yaşam koçundan mentörlük beklerim. *

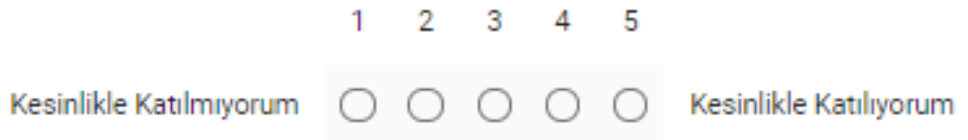

22. Yaşam koçundan rehberlik beklerim. *

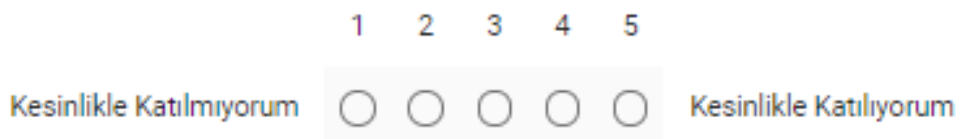


Ocak, S., Yurdakul, D. / Journal of Yasar University, 2021, 16/62, 835-866

23. Yaşam koçu hizmetini almak için internet araştırması yaparım. *
$\begin{array}{lllll}1 & 2 & 3 & 4 & 5\end{array}$
Kesinlikle Katılmıyorum $\bigcirc \bigcirc \bigcirc \bigcirc \bigcirc$ Kesinlikle Katılyorum

24. Yaşam koçluğu hizmetini arkadaş tavsiyesi üzerine alırım. *
$\begin{array}{lllll}1 & 2 & 3 & 4 & 5\end{array}$
Kesinlikle Katılmıyorum $\bigcirc \bigcirc \bigcirc \bigcirc \bigcirc$ Kesinlikle Katllıyorum

25. Yaşam koçluğu hizmetini almak için koçluk örgütlerine başvururum. *
$\begin{array}{lllll}1 & 2 & 3 & 4 & 5\end{array}$
Kesinlikle Katılmıyorum $\bigcirc \bigcirc \bigcirc \bigcirc \bigcirc$ Kesinlikle Katılıorum

26. Yaşam koçluğu hizmeti alırken seans sıklığını göz önünde bulundururum. *

$\begin{array}{llllllll} & 1 & 2 & 3 & 4 & 5 & \\ \text { Kesinlikle Katılmırorum } & \bigcirc & \bigcirc & \bigcirc & \bigcirc & \bigcirc & \text { Kesinlikle Katılıorum }\end{array}$

27. Yaşam koçluğu hizmeti alırken lokasyon değişkeni benim için önemlidir. *

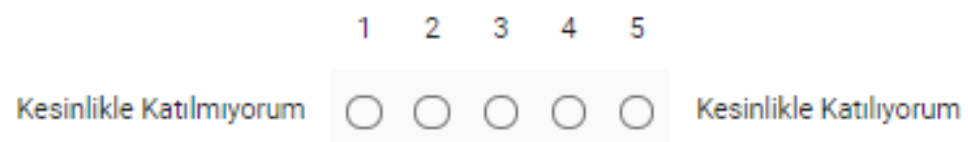

28. Yaşam koçluğu hizmeti alırken koçluk yapacak kişinin eğitim durumunu göz önünde bulundururum. *

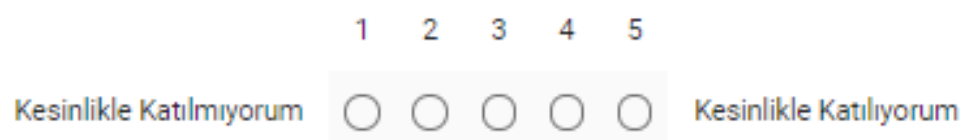

29. Yaşam koçluğu hizmeti alırken koçluk yapacak kişinin tecrübesini göz önünde bulundururum. *

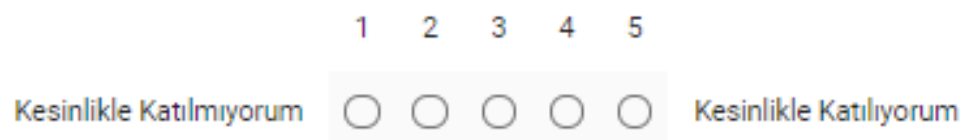


Ocak, S., Yurdakul, D. / Journal of Yasar University, 2021, 16/62, 835-866

30. Yaşam koçluğu hizmeti alırken koçluk yapacak kişinin motivasyonunu göz önünde bulundururum. *

$\begin{array}{lcccccc} & 1 & 2 & 3 & 4 & 5 & \\ \text { Kesinlikle Katılmıorum } & \bigcirc & \bigcirc & \bigcirc & \bigcirc & \bigcirc & \text { Kesinlikle Katillyorum }\end{array}$

31. Yaşam koçluğu hizmetine ayıracağım bütçe benim için önemlidir. *

$\begin{array}{llllllll} & 1 & 2 & 3 & 4 & 5 & \\ \text { Kesinlikle Katılmırorum } & \bigcirc & \bigcirc & \bigcirc & \bigcirc & \bigcirc & \text { Kesinlikle Katıllyorum }\end{array}$

32. Yaşam koçluğu hizmetine ayıracağım süre benim için önemlidir. *

$\begin{array}{llllllll} & 1 & 2 & 3 & 4 & 5 & \\ \text { Kesinlikle Katılmıorum } & \bigcirc & \bigcirc & \bigcirc & \bigcirc & \bigcirc & \text { Kesinlikle Katilyorum }\end{array}$

